\title{
Assessment of Cultural Heritage Tourism Potential in Vietnam
}

\author{
Le Thi Thanh Huyen
}

Scholar; Editor of the Vietnam Review of Peoples and Times; PhD Candidate in Business Administration at Graduate Academy of Social Sciences, Vietnam

E-mail: huyenle0404@gmail.com

Received: March 15, 2020 Accepted: April 28, 2020 Published: May 22, 2020

doi:10.5296/bmh.v8i1.16671ＵRL: http://dx.doi.org/10.5296/bmh.v8i1.16671

\begin{abstract}
Inheriting and developing the Functioning Tourism System (FTS) model of Gunn (Gunn, 1988; Clare, Gunn, \& Turgut Var, 2002), this study assessed the potential of cultural heritage tourism (CHT) in Vietnam. The research results show that the current CHT activities in Vietnam are below the potential. In addition, the study shows that the heritage tourism potential is based on the elements that constitute the tourism system according to the FTS model as destination/attractions, transportation, information, promotion, system of services, travel needs of the community and especially safety and security not only in the area of the tourist destination but also in the whole country. These elements are closely linked with each other and without one of these elements, the tourism system cannot exist and develop. The study also clarifies that the more complete the heritage tourism system, the greater the potential for CHT.
\end{abstract}

Keywords: tourism potential, cultural heritage tourism, FTS system, Vietnam 


\section{Introduction}

Tourism plays a big role in the development of Vietnam; has a great influence on different fields and activities of a country, from economic and trade development, to social and cultural promotion, or creating country's image and nation branding (Huyền, 2020). Vietnam aims to have tourism as a key economic sector by 2030, and Vietnam will be among the countries with the leading developed tourism industries in Southeast Asia (Resolution of Politburo of CPV, 2017). The World Travel \& Tourism Council (WTTC) Report (2019) shows that Vietnam's tourism and travel industry contributed $9.2 \%$ of the national GDP, $7.4 \%$ of total employment and, $3.9 \%$ of total exports of the country in 2018. Figure 1 shows the strong growth of international visitors to Vietnam. Within just 10 years, the growth was $264.3 \%$ from 4,256,740 arrivals in 2008 to $15,497,791$ arrivals in 2018.

Although Vietnam's travel and tourism industry has achieved certain success, there is still no development strategy for the type of "Cultural Heritage Tourism". Meanwhile in the world, "heritage tourism, in line with the global trend in cultural tourism, has emerged as one of the most popular tourism categories" (Chen \& Chen, 2010). Therefore, the assessment of the CHT potential in Vietnam is a necessary issue today. This study was conducted with the aim to further clarify the potential of CHT in Vietnam and thereby better positioning the CHT in particular in the overall tourism industry in Vietnam. The study will focus on answering the following questions:

(1) How to assess the potential of CHT in Vietnam?

(2) What is the potential of CHT in Vietnam?

By qualitative research methods, observing, analyzing survey data, refer to experts, the paper will assess the potential of CHT in Vietnam as a whole and in-depth analysis two typical cases at two destinations that are Van Mieu Quoc Tu Giam (Literature Temple in Ha Noi Capital), a special national relic and the world cultural heritage-Hoi An Ancient Town (Quang Nam Province). 


\section{MInstitute Macrothink}

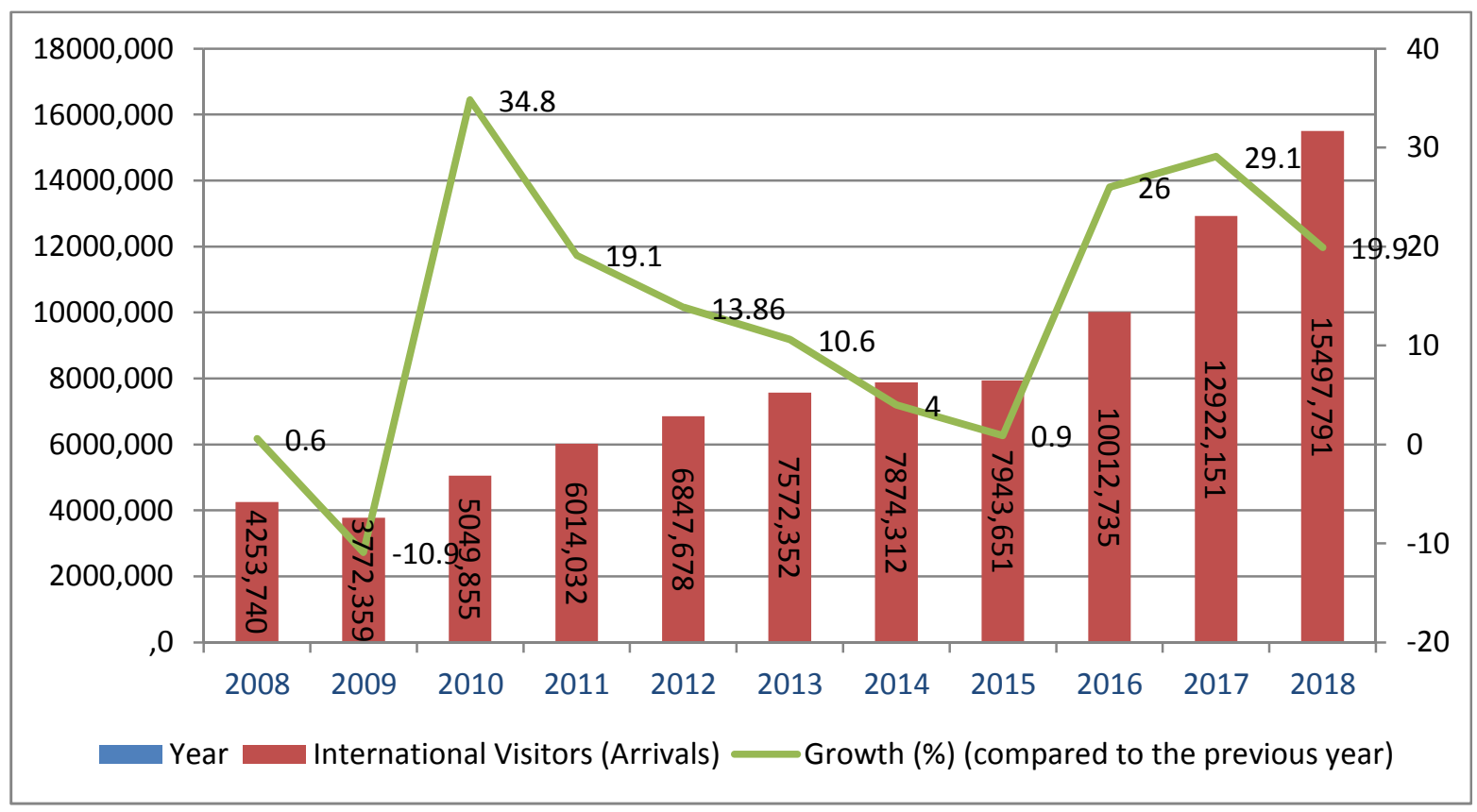

Figure 1. Growth of international visitors to Vietnam (2008-2018) (Source: VNAT, 2009-2019; http://vietnamtourism.gov.vn/index.php/items/28014)

\section{Literature Review}

\subsection{Cultural Heritage Tourism (CHT)}

Heritage tourism is defined as tourism markets and the industry, which have evolved around heritage. There is a vital connection between heritage and tourism (The Travel and Tourism Programme, Ireland; Kamani Perera, n.d). The concept of cultural tourism encompasses a widerange of views embracing a full range of human expressions and manifestations that visitors undertake to experience the heritages, arts, lifestyles, etc. from people living in cultural destinations. Heritage tourism is usually considered to be cultural tourism. Heritage tourism: refers to tourists visiting places of traditional, historical and cultural significance with the aim of learning, paying respect to recreational purposes (Nzama et al., 2005). Hall and Zeppel (1990) said that "Heritage tourism as a synonymous of cultural tourism, is an experiential tourism related to visiting preferred landscape, historic sites, buildings or monuments and seeking an encounter, involvement and stimulation with nature or feeling part of the history of a place". Cultural and heritage tourism can be considered as adynamic activity developed through physical experiences, searching and celebrating what is unique and beautiful, represented by our own values and attributes which are worthy to preserve and to inherit to descendents in such a way that communities can be proud of them (Vargas-Hernández, 2012).

Heritage tourism is concerned with exploring both material and immaterial, i.e., tangible and intangible remnants of the past. Heritage tourism is at present largely characterized by an expanding range of concepts and definitions, by a mix of individual case studies and more 
general discourses (Balcar \& Pearce, 1996, p. 203). Ashworth và Goodall (1990, p. 162) noted that heritage tourism is an idea compounded of many different emotions, including nostalgia, romanticism, aesthetic pleasure and a sense of belonging in time and space. Peterson (1994, p. 121) stated that "we think of heritage tourism as visiting of areas, which make the visitor think of an earlier time". Zeppel and Hall $(1992$, p. 78) also supported the concepts of "nostalgia" and of "special form of tourism", noting that "heritage tourism is a broad field of specialty travel, based on nostalgia for the past and the desire to experience diverse cultural landscapes and forms" (Ramesh \& Usha, 2016). Meanwhile, Silberberg (1995) considered that cultural and heritage tourism is a tool of economic development that achieves economic growth through attracting visitors from outside a host community, who are motivated wholly or in part by interest in the historical, artistic, scientific or lifestyle/heritage offerings of a community, region, group or institution (Rosenfeld, 2008). Another approach, Poria et al. (2001, p. 1048) defined that "Heritage tourism is a phenomenon based on tourist's motivation and perceptions rather than on specific site attributes... Heritage tourism is a subgroup of tourism, in which the main motivation for visiting a site is based on the place's heritage characteristics according to the tourist's perception of their own heritage" (Marianna Sigala \& David Leslie, 2005).

The National Trust for Historic Preservation-NTHP defines heritage tourism as traveling to experience the places, artifacts, and activities that authentically represent the stories and people of the past and present. It includes visitation to cultural, historic, and natural resources (NTHP, 2015). The NTHP pioneered the process for heritage tourism programs in 1990 by identifying five guiding principles: Collaborate; Find the Fit between community and tourism; Make Sites and Programs Come Alive; Focus on Quality and Authenticity; Conservation and protection of resources; and four steps for getting started: Assess the Potential, Plan and Organize, Prepare, Protect, and Manage, Market for Success (Jascha \& Steven, 2011).

Heritage tourism is a type of tourism for practical experiences and knowledge of all that belongs to the past in relation to human life or human physical and mental activities. It is the connection of ideas in reality with what happened in the past, creating feelings of respect, pride and gratitude for the values of the past.

\subsection{Tourism Potential}

Tourism Potential "is a widely used and accepted term in tourism domain, however, sometimes create misunderstanding as potential expresses some territorial capabilities, which holds a little narrower domain" (Abdulla \& Soumen, 2012). As prescribed (Formica, 2000) the term "potential" may be replaced by "Attractiveness" which clearly indicates the relations between demand and supply of tourism. However, several other researches follow the term Potential though this may be assumed to be synonymous to Attractiveness (Bharat, Ravindra, Pravin, \& Nalawade, 2015). Mitrut et al. discusses on potential of tourism in a region by minimizing imbalances of infrastructure within the entire region (Mitruţ, Constantin, \& Gruiescu, 2009). Tourism potential can be defined according to the Explanatory Dictionary of Tourism (Zelenka \& Pásková, 2012, p. 433) as a summary value of all prerequisites of tourism, usually assessed on the basis of a scoring scale, lowered by a negative value of 
negative factors of tourism development, particularly by an adverse state of environmental segments and conflict use of a given area. This definition enables many approaches and views on its evaluation (Jiří Vystoupil, Martin Šauer, \& Ondřej Repík, 2017).

\subsection{The Functioning Tourism System (The FTS)}

The model of tourism functions is clearly mentioned in the study "The Functioning Tourism System" (Gunn, 1988; Clare \& Turgut, 2002) from the perspective of tourism Demand and Supply, then Shelby R. Herrin (2015) adjusted to assess heritage tourism development. This model is well suited to assess the tourism potential of a destination. The FTS refers to the two main drivers of tourism consist of a Demand and a Supply Side that make up the tourism system. Demand is determined by measuring the interest, desire, financial capacity, time and physical ability to travel. Supply is determined through the following five critical macro-level components: Destination is the tourist attractions (cultural values, richness, speciality); Services include a system of services catering to the demand of tourists such as food, accommodation, entertainment, shopping and other services; Transportation includes transport infrastructure (highways, waterways, airway) and means of transport serving tourists; Information including all sources of destination (such as maps, guidebooks, videos, magazines articles, brochures, internet...) to provide to tourists and Promotion for tourism usually encompassed activities (advertising, publicity, public relation and incentives) to advertise to the community about tourist attractions (CA Gunn, 2002; Shelby, 2015 ).

\subsection{The Additional FTS}

In the same opinion with S. Formica (2000) and Zelenka and Pásková (2012), we think that tourism potential is basically values, potential capabilities that can be exploited for succession, development and achieve results in tourism. For CHT in Vietnam, the potential of CHT is the values and potential capabilities that can be exploited for succession, development and achieve results in CHT, including the potential for demand and supply of CHT, in which the supply of CHT is cultural heritage sites (CHS) and services that cater to cultural heritage tourists. These services include food service, entertainment, accommodation, transportation, information promotion and other services.

With the approach from the perspective of tourism supply and demand, it shows that the FTS model proposed by Gunn (2002) and adjusted by Herrin, Shelby R. (2015) are very suitable for assessing tourism potential of a country or a locality. This study will inherit the FTS model and adjust it to suit the new context and conditions of Vietnam.

To carry out this study, the author conducted a survey in May 2019 on "Assessment of the tourism satisfaction on the service quality of CHT in Vietnam" at heritage sites such as Literature Temple, Citadel of the Ho Dynasty, Hoi An Ancient town, Complex of Hue Monuments. We found that the tourists' interest in safety and security is very high and it is even a top important factor when traveling.

With a total sample size of 699, the 5-point Likert-type scale ranging from strongly disagree (1) to strongly agree (5) was used to assess the importance of the 5 factors of tourism supply. Among them, there are 4 factors (Spots of Scenic Beauty, Outstanding Cultural and Historical 


\section{Macrothink}

Values; Quality of Service; Transportation) based on FTS model, and other one (Safety and Security) was added.

The survey results in Table 1 (details in Appendix 1) show that, among the 5 factors, tourists give the highest priority to 3 factors: Safety, Security, Political stability; Spots of Scenic beauty and Outstanding cultural and historical values. The factor of Safety, Security, Political stability are also given priority over the factors of Tourism service qualities and Transportation.

Table 1. The most important factor on tourism supply

\begin{tabular}{|c|c|c|c|c|}
\hline No. & Variables & Code & Ratio $(n=699, \%)$ & Priority \\
\hline 1 & Safety, Security, Political stability & Impofact 45 & $86.0 \%$ & 3 \\
\hline 2 & Spots of Scenic beauty & Impofact46 & $90.8 \%$ & 1 \\
\hline 3 & Outstanding cultural and historical values & Impofact 47 & $89.8 \%$ & 2 \\
\hline 4 & Service qualities & Impofact 48 & $76.5 \%$ & 5 \\
\hline 5 & Convenient transportation & Impofact 49 & $76.8 \%$ & 4 \\
\hline
\end{tabular}

Source. Data analysis results from a direct survey of tourists "Assessment of the tourist satisfaction on the service quality of CHT" at Vietnam's heritage sites, 2018-2019

Therefore, in this study, the author added the factor of Safety and Security to the FTS system to assess the potential of CHT in Vietnam as follows: 
The Functioning Tourism System

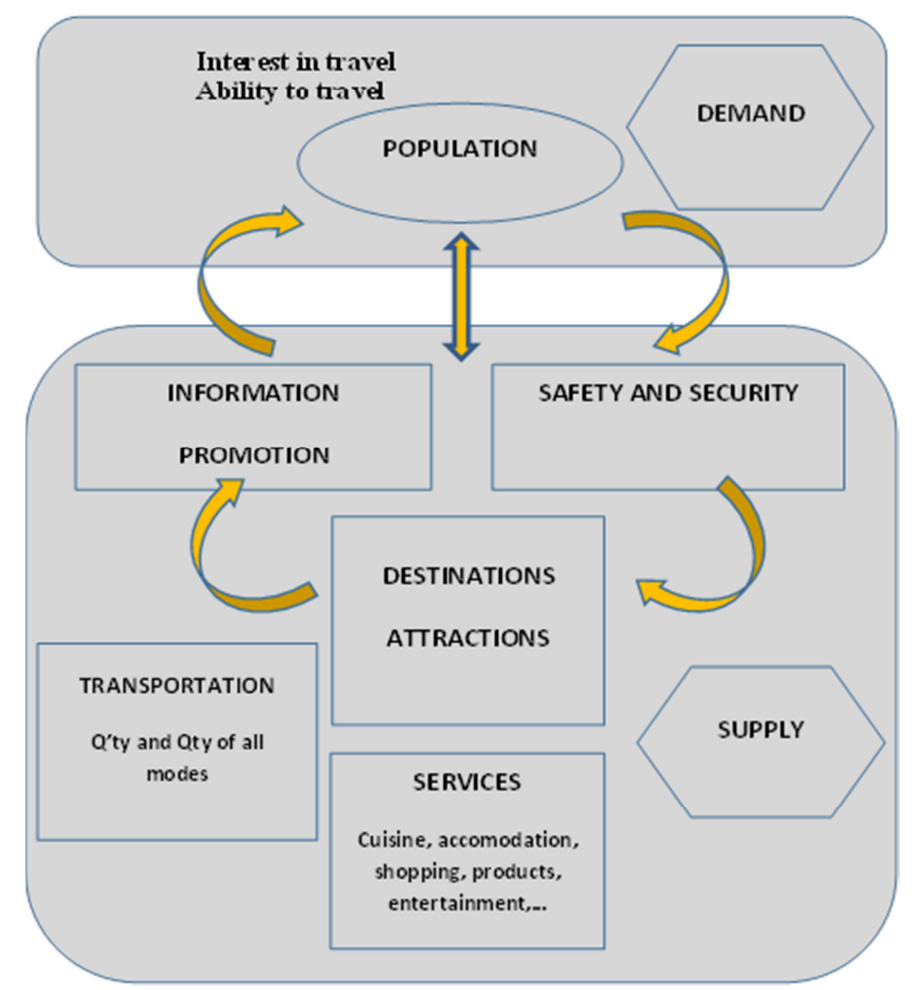

Figure 2. The Additional FTS (Source: Author proposed based on FTS System, Tourism Planning, p. 34 - Clare A. Gunn, 2002; Herrin, Shelby R., "Application of Heritage Tourism Development Frameworks to Jenkins County, Georgia” (2015). University Honors Program Theses. 137. https://digitalcommons.georgiasouthern.edu/honors-theses/137)

Thus, according to the additional FTS as above, to assess the potential of CHT in Vietnam, the study will evaluate two components: (i) Tourism Demand and; (ii) Tourism Supply, including: Destinations (CHS), Services, Transportation, Information Promotion and Safety, Security.

Specific evaluation criteria are as follows, Tourism Demand (H1) is an objective factor that is assessed by the heritage travel trends of tourists (domestic and international); Community awareness about $\mathrm{CHT}$ and the rise of the middle class in society.

Tourism Supply (H2) is determined by the following 5 components:

(C1) Destinations/ Attractions are CHS with evaluation criteria: Historical specificity; Cultural values; Types of tourism; Attractive scenery; Indigenous peoples; Instructions, notes of artifacts; Tour guides, introduction about heritages.

(C2) Services are a system of services that cater to the tourists' needs for cuisine, entertainment, accommodation and others with the evaluation criteria: Diversity of services (multiple choices); Cost of services (High, low, medium); Quality of services. 
(C3) Transportation includes transport infrastructure (highways, waterways, airway) and means of transport serving tourists, with evaluation criteria: Convenience; Reasonable prices; Numerous of vehicles; Behavior and professionalism of the drivers; Safety.

(C4) Information and Promotion with evaluation criteria: Frequency of the communication and promotion; Various types of advertisement and promotion; Ease of access; Awareness of indigenous people.

(C5) Safety and Security with evaluation criteria: Safe and good security; No thief, no robbery; Not life-threatening; Not thrusted when using the services.

\section{Research Methodology}

This research uses a method of surveying tourists' opinions, by collecting data and information through questionnaires. The 5-point Likert-type scale ranging from strongly disagree (1) to strongly agree (5) to be used for the survey questionnaire "Assessment of the tourist satisfaction on the service quality of CHT". In addition, in-depth interviews of experts and methods of observation were used. The collected data will be conducted statistics, classification and coded according to the observed variables and personal information variables and analyzed with the SPSS 20.

About the sample survey size, Barrett \& Kline (1981) stated that the sample size required a minimum of 50, Gorsuch (1983), Kline (1979, p. 4), Maccalum, Widaman, Zhang and Hong (1999, p. 84) stated that at least 100 in then, Guiford (1954, p. 533) suggested 200, Cattell (1978) suggested 250, Aleamoni (1976) was 400. And Comrey and Lee (1992, p. 217) stated that "50-very poor, 100-poor, 200 - normal, 300-good, 500-very good, 1000 or more - excellent". According to the data of the Vietnam National Administration of Tourism (VNAT, 2019), in 2018, total of tourists to Vietnam was estimated at 95,500,000 arrivals. So, this study can use the Slovin's formula (1960) to calculate the sample survey size. Specifically:

$$
n=\frac{N}{N e^{2}+1}
$$

With $\mathrm{n}=$ number of samples, $\mathrm{N}=$ total population, $\mathrm{e}=$ margin of error. In this study, with $\mathrm{e}=$ $5 \%, N=95,500,000$, the required sample survey size equals:

$$
n=\frac{95,500,000}{95,500,000.0,05^{2}+1}=399,99 \sim 400
$$

Following the rule of Comrey and Lee (1992) and referring to the Slovin's formula, this study determined the 700-sample size as well.

Due to constraints of time and budget, this study used a convenient sampling method. The questionnaire will be distributed to all tourists who are present at the two famous CHS of Vietnam (Hoi An Ancient Town and Literature Temple) from November 2018 to May 2019, gaining 699 valid responses (300 of Hoi An; 399 of Literature Temple), among them, 594 responses from international visitors, 105 responses from domestic visitors. 


\section{MInstitute ${ }^{\text {Macrothink }}$}

\section{Findings and Discussion}

\subsection{Characteristics of Respondents}

The characteristics of the respondents are shown in Table 2. The respondents consisted of 699 international and domestic visitors from 3 different national groups of which $70.1 \%$ came from a group of countries with very high HDI, $13.16 \%$ came from a group of countries with high HDI, whereas $16.74 \%$ from the medium HDI national group, no visitors in the low HDI group or the group of other countries or territories in this research sample (According to UNDP 2019, the countries in the world will basically be classified into 5 groups as countries with very high HDI (Human Development Index) (0.8-1), countries with high HDI ( 0.7-0.799), the medium HDI (0.555-0.699), the low HDI $(<0.555)$ and the other countries or territories). Respondents are in a variety of jobs, most of them were employees, followed by students and business managers. Visitors learn about the heritage through various channels of information, $33.3 \%$ of visitors know about the heritage through the sharing of friends and relatives in their country, $20.1 \%$ have got the sharing from friends and relatives abroad, $26.3 \%$ through travel agencies, $37.7 \%$ have got information by the newspaper, television, internet, whereas $1.7 \%$ through their current jobs, $17.1 \%$ remaining through other information channels. Most of the respondents went to the heritage for the first time accounting for $84.4 \%$, whereas $6.4 \%$ for the second time and $9.2 \%$ of visitors for more than 2 times. The tourists traveled to heritages with the main purpose of discovering and admiring the heritage account for $82.1 \%$, learning and researching about the heritage account for $59.9 \%$, whereas $23.7 \%$ for rest and entertainment, $0.7 \%$ of respondents were looking for business opportunities and $1.6 \%$ for other purposes.

Table 2. Characteristics of respondents

\begin{tabular}{llll}
\hline Variable & & $\mathrm{N}$ & $(\%)$ \\
\hline Gender & Male & 321 & 45.9 \\
& Female & 372 & 53.1 \\
& Others & 6 & 0.9 \\
Age (years) & & & \\
& $<25$ & 226 & 32.3 \\
& $25-35$ & 287 & 41.0 \\
& $36-55$ & 108 & 15.4 \\
& $>55$ & 78 & 11.2 \\
National Group (ranked by HDI) & & \\
& Very high & 490 & 70.1 \\
& High & 92 & 13.16 \\
& Medium & 117 & 16.74 \\
Carreer & Low & 0 & 0 \\
& & & 17.2 \\
\hline
\end{tabular}


Business Management

Staffs

Students

Unemployment

Retirement

Others
136

163

130

30

31

89
19.5

23.3

18.6

4.3

4.4

12.7

Travel with

Family

278

39.7

Friends

291

41.6

Colleages

31

4.4

Alone

65

9.3

Others

34

5

Get information of heritage through

Domestic Friends

Friends abroad

Travel agencies

Newspapers, TV, internet...

37.7

Current job

1.7

Others

17.1

Easy to get information of heritage

Yes

661

94.6

No

38

5.4

Travel to the heritage for

The first time

590

84.4

The second

45

6.4

$>2$

64

9.2

Length of stay (days)

1-2

$>7$

129

18.5

Travel with purpose

Learn and research about the heritage 419

Explore, admire the heritage

Rest and entertainment

Looking for business oppotunities

5

0.7

Others

11

1.6

Note. $\mathrm{N}$ is the number of valid samples actually surveyed on the total sample of 699.

\subsection{Demand of CHT}

Vietnam has achieved relatively high economic growth during the past 30 years, with an 
average GDP growth rate of 6-7\%. The population was about 96 million in 2018 . There is an emerging middle class that accounts for $13 \%$ of the population but is expected to reach $26 \%$ of the population by 2026 (The World Bank, 2019). This makes the tourism demand of domestic people increasing every year. Meanwhile, the number of international tourists worldwide in 2018 increased by $6 \%$ to 1.4 billion arrivals - a figure was projected in 2010 that would not be achieved until about 2020 (UNWTO, 2019). According to SRI International (2013), global tourism revenue is estimated at 3.2 trillion dollars, whereas cultural tourism is estimated at 1.1 trillion dollars, accounting for $34.38 \%$ of total revenue of tourism industry. This shows that cultural tourism occupies a leading position compared to other tourism sub-sectors.

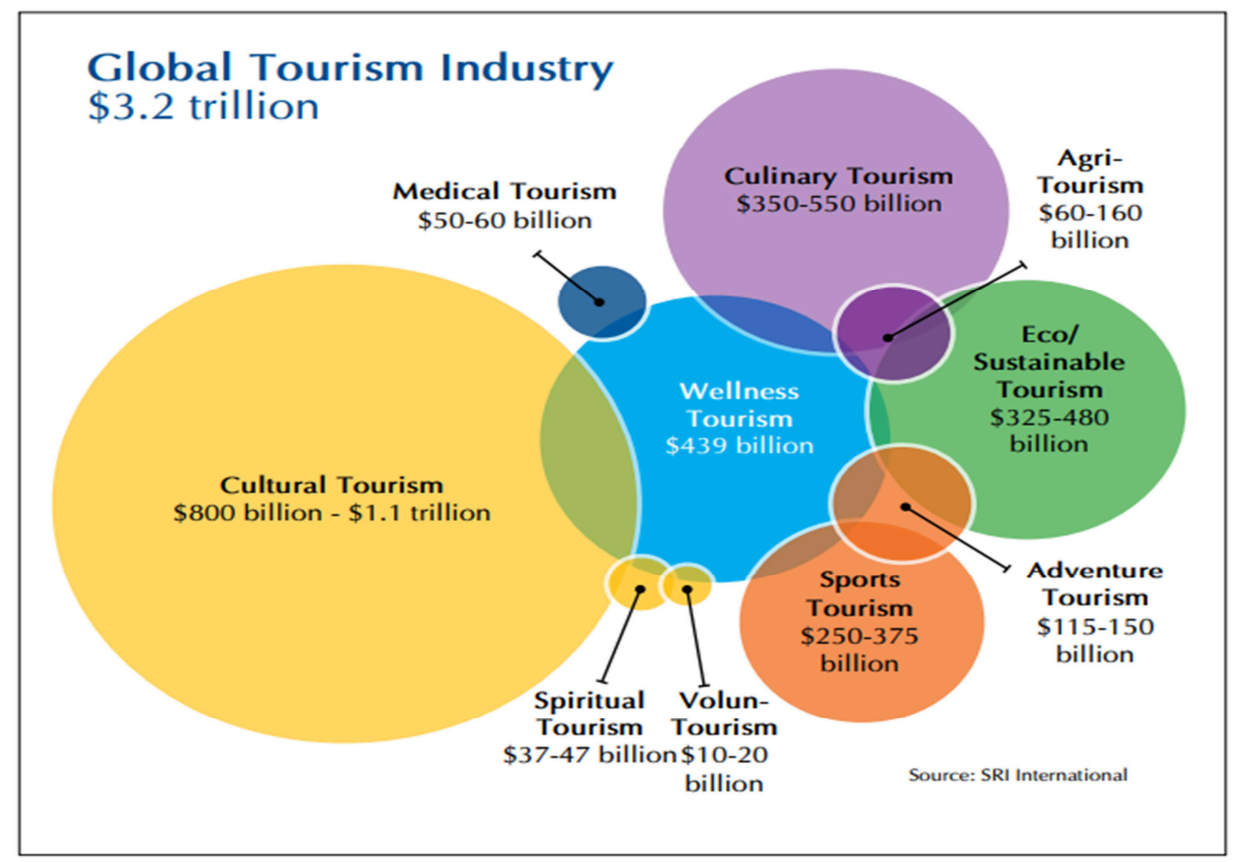

Figure 3. Revenue of global tourism industry (Source: Global Wellness Institute, "The Global Wellness Tourism Economy" (2013),

https:/globalwellnessinstitute.org/industry-research/global-wellness-tourism-economy-2013)

Furthermore, the trend of safe travel of tourists is increasing. Fear of terrorist attacks and insecurity are greatly affecting travel decisions. Besides, Southeast Asia is an area of great tourist interest. On the other hand, tourists around the world are also tending to use high technology and digital information. The internet today is the global travel information standard, and is a source of digital information used by $82 \%$ of travelers around the world. The search for travel information by internet in 2018 was almost double that of 2007 . The internet combined with insights from free sources, is a global standard decision-maker for destination choices of tourists (IPK, 2018).

The survey in this study for international visitors only, "Assessment of tourist satisfaction on the service quality of CHT" in Vietnam shows that $46.7 \%$ of tourists intended to return to heritages and $40.3 \%$ did not know whether they intended to return or not. However, among 
the surveyed travelers, $82.7 \%$ of tourists are willing to recommend friends and relatives to these heritages. This means that these visitors will do buzz marketing and voluntarily advertisement for Vietnam. So, the number of potential tourists coming to Vietnam will continue to increase. Therefore, the international demand for CHT in Vietnam has great potential.

\subsection{Supply of CHT}

\subsubsection{Destinations-CHS}

Vietnam has many UNESCO World Heritage Sites, among them, there are 5 world cultural heritages including Complex of Hue Monuments (recognized in 1993), Hoi An Ancient Town (1999), My Son Sanctuary (1999), Central Sector of the Imperial Citadel of Thang Long Hanoi (2010), Citadel of the Ho Dynasty (2011) and other mixed one is Trang An Landscape Complex (2014). In addition, the representative list of the intangible cultural heritage of humanity identified by UNESCO has 12 Vietnamese cultural heritages such as Practices of Then by Tày, Nùng and Thái ethnic groups in Viet Nam (2019), The art of Bài Chòi in Central Viet Nam and Xoan singing of Phú Thọ province, Viet Nam (2017), Practices related to the Viet beliefs in the Mother Goddesses of Three Realms (2016), Ví and Giặm folk songs of Nghệ Tĩnh (2014) etc.

In addition, Vietnam has about 3000 national heritage sites and 7500 provincial heritage sites and many other cultures, customs, habits, and landscapes. Those are important advantages to attract tourists to Vietnam. With a rich and diverse range of cultural heritage types, on the list of the most desirable countries in Asia, Vietnam has a great potential to exploit and develop heritage tourism. Overall national review, Vietnam has a central geographic location in Asia with a beautiful long coastline, a stable political system, a dynamic economy, and an open foreign policy that is gradually improving national image. Vietnam is a destination for business cooperation and organizing events (Huyền, 2020).

Besides the overall of the national CHS, are details of the world CHS of Hoi An Ancient Town and the special national relics of Literature Temple. Analysis of data from the survey, the results are shown in Table 3 with $88.8 \%$ of tourists agreed that history of heritages are special and unique; more than $90 \%$ of them said that heritages have rich cultural values. However, the weakness of CHS comes from the team of tour guides, the instructions and notes of artifacts. Hoi An was judged lower than Literature Temple with 53.5\% of tourists said that instructions, notes of artifacts in Hoi An are clear, detailed and scientific and only $37.8 \%$ of them stated that tour guides presented about heritages with qualified, clear and professional knowledge. 
Table 3. Assessment of tourists for Hoi An Ancient Town and Literature Temple

\begin{tabular}{llccc}
\hline No. Content & & $\begin{array}{c}\text { Ratio Average } \\
\text { (agree/strongly } \\
\text { agree })\end{array}$ & $\begin{array}{c}\text { Literature } \\
\text { Temple }\end{array}$ & $\begin{array}{c}\text { Hoi An } \\
\text { Ancient } \\
\text { Town }\end{array}$ \\
\cline { 3 - 5 } & & 88.8 & 91.5 & 86.1 \\
\hline 1 & Special/ unique in heritage history & 90.7 & 92.3 & 89.1 \\
2 & Rich cultural value & 67.65 & 66.6 & 68.7 \\
3 & Numerous types of tourism & 89.1 & 89.2 & 89 \\
4 & Attractive scenery & 82.75 & 82.8 & 82.7 \\
5 & $\begin{array}{l}\text { Indigenous peoples are friendly and } \\
\text { hospitable }\end{array}$ & & 76.6 & 53.5 \\
6 & $\begin{array}{l}\text { Instructions, notes of artifacts are } \\
\text { clear, detailed and scientific }\end{array}$ & 65.05 & & \\
7 & $\begin{array}{l}\text { Tour guides present about heritages } \\
\text { are qualified, clear and professional }\end{array}$ & 48.7 & 59.6 & 37.8 \\
\hline
\end{tabular}

Source: Data analysis results.

Nevertheless, with the wealth of Vietnam's heritage resources and its unique historical cultural value or the fascinating landscape in heritage area or the friendly and hospitable indigenous peoples like objective reviews of tourists, Vietnam is a country with great potential for supply of CHS. The supply of CHS is also one of the six important factors that constitute a complete CHT system. Thereby we see that the huge potential of the supply of CHS is one of the six pillars that create the potential of the CHT industry in general and of Vietnam in particular.

\subsubsection{Transportation}

Vietnam's transportation system is rapidly improving with a full range of modes of transportation that basically meet the needs of tourists to regions and tourist destinations, including roads, railway, waterway and airway.

In recent years, Vietnam has prioritized investment in developing the road system. In addition, the Vietnam Transport Industry aims to invest about 2,500 km of highways by the end of 2020 and $6.411 \mathrm{~km}$ of highways by 2030 . This will be a strategy to develop infrastructure as a platform to connect tourists with domestic tourism destinations.

About railway system which is considered to be the most outdated in Vietnam has also changed steps. According to the Vietnam Ministry of Transport in "Adjusting the Strategy of Vietnam Transport Development to 2020 and vision to 2030", Vietnam has a total length of $3,143 \mathrm{~km}$ of railroads including $2,531 \mathrm{~km}$ of main routes, $612 \mathrm{~km}$ of branches and railway 
lines. Meanwhile, the system of domestic waterways, ports and harbours has about 2,360 rivers and canals, with a total length of $41,900 \mathrm{~km}$ and 108 domestic ports and wharves which are scattered on main canals and rivers. Vietnam is in the process of implementing the construction of international gateway ports in the key economic regions and wharves in other areas. In addition, the sea system with more than 3,200 km of coastline and 37 seaports, 166 harbours, 350 wharves (JICA, 2010) that have contributed to the development of Vietnam's tourism industry. About airway system, is one of the most important infrastructure for tourism development. Currently, Vietnam has 22 airports, including 13 domestic airports and 9 international ports. With a system of many airlines serving continuously, tourists can easily come to Vietnam to experience travels. With the increasingly renovated and developed infrastructure and the abundant means of transport basically meet the needs of tourists to regions and areas.

The data analysis results show that the assessments and satisfaction level of tourists for transportation at the CHS are quite good (see Appendix 2). In the Table 4, 69.4\% of tourists agreed that transportation at CHS is convenient. Regarding prices and costs, $75.4 \%$ of tourists said that is reasonable. Whereas $73.7 \%$ said that the types of vehicles at the heritage sites are numerous. Besides, only $57.7 \%$ of tourists agreed that drivers are good behavior and professional. Moreover, the safety factor in transportation, only $47.1 \%$ of tourists said that is safe.

Table 4. Quality valuation statistic of transportation

\begin{tabular}{|c|c|c|c|c|c|}
\hline \multirow[t]{2}{*}{ No. } & \multirow[t]{2}{*}{ Variable } & \multirow[t]{2}{*}{ Code } & \multicolumn{3}{|l|}{ Ratio $(\mathrm{n}=699, \%)$} \\
\hline & & & $\begin{array}{l}\text { Agree/ strongly } \\
\text { agree }\end{array}$ & Neutral & $\begin{array}{l}\text { Disagree/ } \\
\text { strongly } \\
\text { disagree }\end{array}$ \\
\hline 1 & Convenient & TRANSF26 & $69.4 \%$ & $24.6 \%$ & $5.5 \%$ \\
\hline 2 & Resonable prices & TRANSF27 & $75.4 \%$ & $20.0 \%$ & $4.4 \%$ \\
\hline 3 & $\begin{array}{l}\text { Numerous of vehicles (taxi, trams, } \\
\text { motorcycle-taxi, trains...) }\end{array}$ & TRANSF28 & $73.7 \%$ & $20.9 \%$ & $5.0 \%$ \\
\hline 4 & $\begin{array}{l}\text { Behavior and professionalism of the } \\
\text { drivers }\end{array}$ & TRANSF29 & $57.7 \%$ & $31.6 \%$ & $10.6 \%$ \\
\hline 5 & Safety & TRANSF30 & $47.1 \%$ & $34.7 \%$ & $18.0 \%$ \\
\hline 6 & Satisfied with the transportation services & TRANSF31 & $67 \%$ & $27.4 \%$ & $5.5 \%$ \\
\hline
\end{tabular}

Source: Data analysis results. 
Overall, $67 \%$ of tourists were satisfied with transportation at CHS, in addition, the policies, plans to continue changing, renovating and upgrading the transportation system of the Vietnamese government with a vision to 2030, one thing is for sure that the potential for developing and innovating the transportation system in Vietnam is large. Therefore, it will fully meet the needs of tourists to Vietnam in the near future.

\subsubsection{Information and Promotion}

Information and promotion are ways for the community to know about destinations and tourism services of cultural heritage in Vietnam in particular. Vietnam has had various, diversified and copious marketing and promotion strategies, not only in terms of information but also in terms of advertising.

Vietnam National Administration of Tourism (VNAT) has many programs to promote tourism activities such as conferences, events, exhibition activities with the aim of introducing and promoting to the domestic people and international friends (VNAT, 2019). Besides, a series of electronic information channels with a lot of information about Vietnam tourism with diverse and rich contents such as how to travel to Vietnam as well as tourist destinations. The information is supplied by domestic and foreign organizations or management agencies such as VNAT, heritage management agencies, even the information pages of people traveling through social networks or personal blogs that are increasingly popular and rich.

Communication and promotion are not only in the country, Vietnam has also gained a lot of popularity with international media such as Hanoi tourism which has been positively evaluated by many travel websites, international television and press in the world, for example, CNN, Discovery or Business Insider. For example, CNN names Hoi An among Asia's most picturesque towns (CNN, 2019) or Hoi An is one of the 10 best cities in Asia by Travel and Leisure, USA (Travel and Leisure, 2019). Many important cultural and tourist events, aiming to introduce, advertise and honor the value of Vietnam's unique cultural heritages, especially the Vietnamese Cultural Heritage recognized by UNESCO. For example, the event "The first Vietnam Cultural Heritage Day 2018" was held at the Imperial Citadel of Thang Long-Hanoi on November, 23-24, 2018. However, the activities of CHT in reality have not been paid much attention. Currently, the promotion activities are still geared towards coastal tourism, ecotourism, spiritual tourism but have not yet promoted CHT.

The data analysis results (see Appendix 3) show that the assessments and the level of tourists' satisfaction with the information and promotion at the heritage sites is rated with the minimum is 1 , maximum is 5 , the median is greater than 3 , the standard deviation is less than 1. $52.6 \%$ of tourists agreed that the frequency of the advertise about heritage destinations was large whereas $46.7 \%$ of them agreed that channels are rich. $66.5 \%$ of tourists agreed that information is easy to access. Otherwise, $58.3 \%$ of tourists agreed that there are lot of heritage events. Another important assessment is that "Awareness of indigenous people about heritage conservation", only $45.2 \%$ of tourists thought that consciousness is high. This shows that even indigenous people are not really aware of the deep and clear about values of heritage. Therefore, the pride of the heritage of indigenous people is not really great in order to they can better communicate or promote their own heritage. Therefore, Vietnam must have 
ways to raise awareness of indigenous peoples as well as the community to better understand and deeply appreciate the values of heritages so that the heritage pride can be built in deeply within each indigenous person as well as the community in general.

Table 5. Quality valuation statistic of information and promotion

\begin{tabular}{|c|c|c|c|c|c|}
\hline \multirow[t]{2}{*}{ No. } & \multirow[t]{2}{*}{ Variable } & \multirow[t]{2}{*}{ Code } & \multicolumn{3}{|c|}{ Ratio $(n=699, \%)$} \\
\hline & & & $\begin{array}{c}\text { Agree/ } \\
\text { strongly } \\
\text { agree }\end{array}$ & Neutral & $\begin{array}{c}\text { Disagree/ } \\
\text { strongly } \\
\text { disagree }\end{array}$ \\
\hline 1 & $\begin{array}{l}\text { Frequency of the advertise about } \\
\text { heritage destinations }\end{array}$ & PROM32 & $52.6 \%$ & $39.9 \%$ & $7.4 \%$ \\
\hline 2 & Rich information channels & PROM33 & $46.7 \%$ & $44.9 \%$ & $8.3 \%$ \\
\hline 3 & Easy access to information & PROM34 & $66.5 \%$ & $28.7 \%$ & $4.7 \%$ \\
\hline 4 & Numerous of heritage events & PROM35 & $58.3 \%$ & $37.0 \%$ & $4.6 \%$ \\
\hline 5 & $\begin{array}{l}\text { Awareness of indigenous people } \\
\text { about heritage conservation is high }\end{array}$ & PROM36 & $45.2 \%$ & $36.7 \%$ & $8.0 \%$ \\
\hline
\end{tabular}

Source. Data analysis results.

Information and promotion are limited and tourists' reviews show that communication at the heritage sites currently is not good. However, this factor can improve, change, upgrade, develop, even remove the old, outdated or unreasonable things to replace the new, the rational and catch up the general trend of the world. For example, using digital media, social networks to promote heritages to international tourists in a short time (like a week, a day, an hour) without having to wait the annual travel exhibition or festival events.

Therefore, the potential of communication promotion is very large, especially in the present age, the relentless development and extremely fast of digital technology has made communication and marketing easier and richer than ever.

\subsubsection{Tourism Services}

As of 2018, Vietnam has 2020 international travel businesses (VNAT, 2019). Major brands in Vietnam's tourism industry such as Saigon Tourist, Benthanh Tourist, Hanoi Red Tour, Holidays Vietnam, Vietravel, Fiditour, Vietcharm Travel, Hanoitourist etc. Most travel companies actively engage with local service providers where heritage sites exist to provide 
services to customers. Prices of services are generally lower than those of regional countries. The types of services are also quite diverse and recognized by international tourists, such as food, accommodation and entertainment.

The results of the survey "Assessement of the tourist satisfaction on the service quality of CHT" at the heritage sites show that the assessments and satisfaction level of tourists for services at the heritage sites are good. Specifically:

\section{Cuisine services}

All of six contents of assessment (see Table 6) achieved good reviews of tourists, with $78.6 \%$ of tourists said that the variety of cuisine, $78.3 \%$ agreed that the price of food services at the heritage site is reasonable whereas $80.7 \%$ rated that the food was attractive and fascinated, $78.4 \%$ agreed that the service quality was good and in terms of safe food, the percentage of tourists agreed to reduce to $65 \%$. However, overall assessment, $81.1 \%$ of visitors are satisfied with the food services at the heritages. Survey results show that the culinary services at the CHS is good. However, the suppliers of cuisine services need to improve better the quality and quantity of services, especially food safety issues.

Table 6. Quality valuation statistic of Cuisine service

\begin{tabular}{|c|c|c|c|c|c|}
\hline \multirow[t]{2}{*}{ No. } & \multirow[t]{2}{*}{ Variable } & \multirow[t]{2}{*}{ Code } & \multicolumn{3}{|c|}{ Ratio $(n=699, \%)$} \\
\hline & & & $\begin{array}{l}\text { Agree/ } \\
\text { strongly } \\
\text { agree }\end{array}$ & Neutral & $\begin{array}{l}\text { Disagree/ } \\
\text { strongly } \\
\text { disagree }\end{array}$ \\
\hline 1 & Variety in terms of cuisine types & CUS8 & $78.6 \%$ & $18.6 \%$ & $3.7 \%$ \\
\hline 2 & Reasonable prices & CUS9 & $78.3 \%$ & $17.6 \%$ & $4.0 \%$ \\
\hline 3 & Attractive dishes & CUS10 & $80.7 \%$ & $16.7 \%$ & $2.4 \%$ \\
\hline 4 & Good service qualities & CUS11 & $78.4 \%$ & $18.1 \%$ & $3.2 \%$ \\
\hline 5 & Safety food & CUS12 & $65.0 \%$ & $29.3 \%$ & $5.5 \%$ \\
\hline 6 & Satisfied with the cuisine service & CUS13 & $81.1 \%$ & $15.7 \%$ & $3.0 \%$ \\
\hline
\end{tabular}

Source: Data analysis results. 
Entertainment services

In the Table 7, there are 6 contents which achieved the average rating of tourists, with $64.5 \%$ of visitors stated that the variety of entertainment types, $67 \%$ agreed that the prices of entertainment services at the heritage sites are reasonable while $59.5 \%$ of tourists thought that the entertainment contents are attractive, $61.1 \%$ agreed that with the folk arts are unique and excellent and $66.7 \%$ evaluated that the service qualities are good. Overall, compared to the cuisine services, the rate of tourists satisfied with entertainment services at these heritage sites dropped to $66.6 \%, 30.9 \%$ of them were neutral while $2.4 \%$ of visitors were unhappy about the entertainment services at the CHS. The survey results show that entertainment services at the heritages are still not rich and diverse, there are many limitations in terms of quality and content. Therefore, entertainment service businesses need to improve their existing entertainment content, change, upgrade and add new entertainment contents and activities to meet better for tourists demand and contribute to enriching the chain of entertainment services in the heritages.

Table 7. Quality valuation statistic of entertainment

\begin{tabular}{|c|c|c|c|c|c|}
\hline \multirow[t]{2}{*}{ No. } & \multirow[t]{2}{*}{ Variable } & \multirow[t]{2}{*}{ Code } & \multicolumn{3}{|c|}{ Ratio $(\mathrm{n}=699, \%)$} \\
\hline & & & $\begin{array}{l}\text { Agree/ } \\
\text { strongly } \\
\text { agree }\end{array}$ & Neutral & $\begin{array}{l}\text { Disagree/ } \\
\text { strongly } \\
\text { disagree }\end{array}$ \\
\hline 1 & Variety of entertainment types & ENT14 & $64.5 \%$ & $31.1 \%$ & $4.2 \%$ \\
\hline 2 & Reasonable prices & ENT15 & $67.0 \%$ & $29.3 \%$ & $3.6 \%$ \\
\hline 3 & Intriguing entertainment content & ENT16 & $59.5 \%$ & $37.7 \%$ & $2.6 \%$ \\
\hline 4 & Excellent folk arts & ENT17 & $61.1 \%$ & $35.6 \%$ & $2.9 \%$ \\
\hline 5 & Good service qualities & ENT18 & $66.7 \%$ & $30.7 \%$ & $2.5 \%$ \\
\hline 6 & $\begin{array}{l}\text { Satisfied with the entertainment } \\
\text { service }\end{array}$ & ENT19 & $66.6 \%$ & $30.9 \%$ & $2.4 \%$ \\
\hline
\end{tabular}

Source: Data analysis results.

\section{Accommodation services}

The statistic in the Table 8 shows that the accommodation services at the heritages are good 
at both quality and quantity. Six contents of measurement of accommodation services have achieved good customer reviews, with $86.7 \%$ of visitors said that the accommodation types are varied with many hotels, motels, homestays etc., $83.4 \%$ agreed that the price of accommodation services at the heritage sites is reasonable, $79 \%$ rated that the accommodation services have full facilities, $83.8 \%$ agreed that the service qualities are good, $81.5 \%$ of tourists stated that the customer services (local tour connection, logistics, information...) are good. It is a joyous signal when $85.8 \%$ of visitors satisfied with the accommodation service at the heritage.

Table 8. Quality valuation statistic of accomodation service

\begin{tabular}{|c|c|c|c|c|c|}
\hline \multirow[t]{2}{*}{ No. } & \multirow[t]{2}{*}{ Variable } & \multirow[t]{2}{*}{ Code } & \multicolumn{3}{|c|}{ Ratio $(\mathrm{n}=699, \%)$} \\
\hline & & & $\begin{array}{l}\text { Agree/ } \\
\text { strongly } \\
\text { agree }\end{array}$ & Neutral & $\begin{array}{l}\text { Disagree/ } \\
\text { strongly } \\
\text { disagree }\end{array}$ \\
\hline 1 & $\begin{array}{l}\text { Variety of accommodation types (hotel, } \\
\text { motel, home-stay, hostel...) }\end{array}$ & $\mathrm{ACCO} 20$ & $86.7 \%$ & $11.0 \%$ & $2.1 \%$ \\
\hline 2 & Reasonable prices & $\mathrm{ACCO} 21$ & $83.4 \%$ & $14.4 \%$ & $2.0 \%$ \\
\hline 3 & Full facilities & $\mathrm{ACCO} 22$ & $79.0 \%$ & $19.0 \%$ & $1.8 \%$ \\
\hline 4 & Good service qualities & $\mathrm{ACCO} 23$ & $83.8 \%$ & $13.7 \%$ & $2.3 \%$ \\
\hline 5 & $\begin{array}{l}\text { Good customer service (Local tour } \\
\text { connection, logistics, information...) }\end{array}$ & $\mathrm{ACCO} 24$ & $81.5 \%$ & $16.1 \%$ & $2.0 \%$ \\
\hline 6 & $\begin{array}{l}\text { Satisfied with the accommodation } \\
\text { services }\end{array}$ & $\mathrm{ACCO} 25$ & $85.8 \%$ & $12.3 \%$ & $1.7 \%$ \\
\hline
\end{tabular}

Source: Data analysis results.

However, overall assessment, tourism services in Vietnam are still limited such as the price difference between domestic and international visitors in the localities; Service activities in some localities show signs of manipulation and poor civilization; Human resources in the tourism industry are not fluent in foreign languages, limited in professional knowledge and lack of professionalism ... In addition, inter-regional connectivity in tourism or in the chains of tourism in Vietnam is limited. 


\subsubsection{Safety and Security}

Vietnam is a country with stable politics and good security. Vietnam in general as well as localities or heritage tourism sites in particular which achieved a high rate of appreciation for safety and security. The data analysis results show that the assessments and satisfaction level of tourists for safety and security at the heritage sites are good. In the Table 9, 73.9\% of visitors rated safety and security at the heritage sites are good, $79.1 \%$ found that there were no thieves and robberies, $83.7 \%$ of visitors rated not life-threatening, $68.8 \%$ of visitors reviewed that is not thrusted and manipulated when using the services.

However, the above assessments are still quite good, which is not excellent because there is one factor, that is traffic safety. Vietnam has a high level of traffic safety risk. Results of direct interviews, the majority of remaining tourists said that traffic in Vietnam is very dangerous. They believe that their lives are threatened when traveling on the road in Vietnam. In addition, there is still a great deal of manipulation when using the service at heritage sites.

Table 9. Quality valuation statistic of safety and security

\begin{tabular}{|c|c|c|c|c|c|}
\hline \multirow[t]{2}{*}{ No. } & \multirow[t]{2}{*}{ Variable } & \multirow[t]{2}{*}{ Code } & \multicolumn{3}{|c|}{ Ratio $(n=699, \%)$} \\
\hline & & & $\begin{array}{l}\text { Agree/ } \\
\text { strongly } \\
\text { agree }\end{array}$ & Neutral & $\begin{array}{l}\text { Disagree/ } \\
\text { strongly } \\
\text { disagree }\end{array}$ \\
\hline 1 & Good securities & SECUR37 & $73.9 \%$ & $22.1 \%$ & $3.9 \%$ \\
\hline 2 & No thief, no robbery & SECUR38 & $79.1 \%$ & $17.0 \%$ & $3.7 \%$ \\
\hline 3 & Not life-threatened & SECUR39 & $83.7 \%$ & $13.6 \%$ & $2.6 \%$ \\
\hline 4 & Not thrusted when using the services & SECUR40 & $68.8 \%$ & $22.0 \%$ & $8.9 \%$ \\
\hline
\end{tabular}

Source: Data analysis results.

Although there are some restrictions on safety and security factor, but Vietnam is generally a politically stable country, and safe for all when traveling to Vietnam. And the factors of safety and security will continue to be improved and upgraded in parallel with the development of all aspects of the Vietnamese nation.

\section{Conclusion and Implication}

The potential of CHT in Vietnam is enormous. The above analysis clearly shows the abundant resources, values and potential capabilities of the six factors that constitute the complete CHT 
system in Vietnam today. The resources have not been properly exploited and developed and in accordance with their inherent potential. There are many factors that are being neglected, slow compared to the trend such as information promotion. There are factors that do not meet the growth and demand of society such as transportation or Vietnam's heritage sites are not properly perceived by the domestic community for their inherent value, nor are they known to the world community as well as other famous heritage sites in the world.

In order to fully exploit the potential of CHT in Vietnam, it is necessary to have a comprehensive development strategy, combining factors together in a complete system, no difference or no gap between the factors. We cannot just focus on preserving and protecting the heritage sites well but neglecting the quality of services such as food, accommodation etc... Or the promotion for CHT strongly but transportation is difficult, transport infrastructure is poor. Factors should be implemented synchronously, closely, completely. Specifically:

(i) Demand of CHT: Raising awareness of the community on heritages, values of local, national or world heritages. Using communication methods to increase the pride of the heritages, thereby, will enhance the sense of self-preservation and protection of heritages in the local community and the host country. Make it easier for international visitors to travel to Vietnam's cultural heritages such as being more open to granting visas or easily accessing information about Vietnam's cultural heritages by programs of promotion, marketing or media on Vietnamese cultural heritages. (ii) For CHS: Preserving and protecting the heritages are not only the responsibility of state management agencies but also the responsibility of the whole society. Therefore, policies and laws on national and local heritage conservation and protection need to be clear, specific and have strict sanctions against violations. It is necessary to raise the awareness of local people or indigenous communities on the self-protection and conservation of national heritages in general and of the localities in particular. Thereby, the cultural heritage itself has been an invaluable resource, going along its history and increasing its value over time. In addition, the team of guides and speakers on the heritage need to improve their qualifications and standardize their specialties, especially foreign languages. It is the tour guides and speakers who are important links to connect visitors with the heritages and further increase the perception of visitors about the value of the heritage. (iii) For transportation, there is a need for further development, especially the connection between tourist destinations. (iv) For information and communication: Developing national-level communication strategies, promotion and marketing strategies for Vietnam's CHT; Enhancing the marketing and development activities diversify heritage communication products. A heritage map of Vietnam should be created to strengthen and mutually support each other. (v) For the service system: it is necessary to closely connect the services together and create certain standards of services and develop them into a professional system. The service system in this heritage is linked and mutual with systems in other heritages. In addition, it is necessary to improve the regulations on the management of tourism services, prevent and eliminate the situation of organizing illegal tours, improve the quality and effectiveness of serving activities of tour organization. (vi) For safety and security factor, Vietnam needs to step up its activities to ensure traffic safety. In addition, strengthening the management of service quality and tourism security, eliminating price pressures, theft, decoys, etc at tourist attractions. 


\section{References}

Abdulla, A. M., \& Soumen, M. (2012). A Methodology for Assessing Tourism Potential: Case Study Murshidabad District, West Bengal, India. International Journal of Scientific and Research Publications, 1-8.

Bharat, L. G., Ravindra, G. J., \& Pravin, M. N. (2015). An Assessment of Tourism Potential: A Case Study of Nashik City, Maharashtra. International Journal of Research in Geography (IJRG), 8-12.

Bob, M., \& Hilary, D. C. (2002). Cultural Tourism: The Partnership Between Tourism and Cultural Heritage Management. New York and London: Routledge, Taylor\&Francis.

Clare, A. G., \& Turgut, V. (2002). Tourism Planning. London: Routledge, Taylor and Francis. CNN. (2019a). 13 of Asia's most picturesque towns. Retrieved from https://edition.cnn.com/; https://edition.cnn.com/travel/article/asia-beautiful-towns/index.html

CNN. (2019b). Best places to visit for the ultimate Asia experience. Retrieved from https://edition.cnn.com/;

https://edition.cnn.com/travel/article/asia-best-places-to-visit/index.html

Global Wellness Institute. (2013). The Global Wellness Tourism Economy 2013. Retrieved from

globalwellnessinstitute.org:

https://globalwellnessinstitute.org/industry-research/global-wellness-tourism-economy-2013/

Gunn, C. A. (1988). Tourism Planning. New York: Taylor \& Francis.

Herrin, S. R. (2015). Application of Heritage Tourism Development Frameworks to Jenkins

County, Georgia. Retrieved from https://digitalcommons.georgiasouthern.edu/cgi/viewcontent.cgi?article=1106\&context=hono rs-theses

Huyền, L. T. (2020). Vietnam-India tourism cooperation: An evaluation of status and potential. In R. G. Jayachandra \& N. X. Trung (Eds.), India - Vietnam Enhacing Partnership. Delhi, India: Narendra Publishing House.

Jascha, M. Z., \& Steven, W. B. (2011). A Heritage Tourism Overview. Retrieved from https://extension.usu.edu/iort/ou-files/IORT_021.pdf

JICA. (2010). Nghiên cưu toàn diện phát triển giao thông vận tải bền vũng ở Việt Nam (VITRANSS 2). Retrieved from https://openjicareport.jica.go.jp/; https://openjicareport.jica.go.jp/700/700/700_123_12000063.html

Jiř́, V., Martin, Š., \& Ondřej, R. (2017). Quantitative analysis of tourism potential in the Czech Republic. Acta Universitatis Agriculturae et Silviculturae Mendelianae Brunensis, 1085-1098. https://doi.org/10.11118/actaun201765031085

Marianna, S., \& David, L. (2005). International cultural tourism: management, implications and cases. Great Britain: Elsevier Ltd. . 
Mitruţ, C., Constantin, D.-L., \& Gruiescu, M. (2009). Tourism potential and the diminishing of regional disparities in Romania. Retrieved from http://steconomiceuoradea.ro/wp/; http://steconomiceuoradea.ro/anale/volume/2009/v2-economy-and-business-administration/2 5.pdf

NTHP. (2015). [Preservation Glossary] Today's Word: Heritage Tourism. Retrieved from https://savingplaces.org/stories/preservation-glossary-todays-word-heritage-tourism\#.XkqNJ TIzbIV

Nzama, A. T., Magi, L. M., \& Ngcobo, N. R. (2005). Workbook-I TourismWorkbook for Educators: 2004 Curriculum Statement. Unpublished Tourism Workshop Educational Materials. Centre for Recreation \&Tourism, UZ. and Tourism KwaZulu-Natal.

Perera, K. (n.d.). The Role of Museums in Cultural and Heritage Tourism for Sustainable Economy in Developing Countries. Retrieved from https://www.ne-mo.org/; https://www.ne-mo.org/fileadmin/Dateien/public/statements_and_news/Reading_Corner/Cult ural_and_Heritage_Tourism.pdf

Ramesh, R. K., \& Usha, C. (2016). Natural Disaster and Heritage Tourism: A Study on the Impacts of Earthquake in Bhaktapur, Nepal. Journal of Tourism and Hospitality, 6, 1-39. https://doi.org/10.3126/jthe.v6i0.14766

Resolution of Politburo of CPV. (2017). Nghị quyết của Bộ Chính trị. Retrieved from https://thuvienphapluat.vn/van-ban/Thuong-mai/Nghi-quyet-so-08-NQ-TW-phat-trien-du-lic h-tro-thanh-nganh-kinh-te-mui-nhon-2017-338542.aspx

The World Bank. (2019). Overview. Retrieved from https://www.worldbank.org/; https://www.worldbank.org/en/country/vietnam/overview

Travel and Leisure. (2019). The Top 10 Cities in Asia. Retrieved from www.travelandleisure.com: https://www.travelandleisure.com/worlds-best/cities-in-asia

UNDP. (2019). Table 1: Human Development Index and its components. Retrieved from http://hdr.undp.org/;

http://hdr.undp.org/en/content/table-1-human-development-index-and-its-components-1

UNESCO. (2019). Browse the Lists of Intangible Cultural Heritage and the Register of good safeguarding practices. Retrieved from https://ich.unesco.org/; https://ich.unesco.org/en/lists?multinational=3\&type[]=00002\&display1=inscriptionID\#tabs

UNWTO. (2019). International Tourist Arrivals Reach 1.4 Billion two years ahead of Forecasts. $\quad$ Retrieved from https://www.unwto.org/; https://www.unwto.org/global/press-release/2019-01-21/international-tourist-arrivals-reach-1 4-billion-two-years-ahead-forecasts

Vargas-Hernández, J. G. (2012). Normative Model for Sustainable Cultural and HeritageTourism in Regional Development of Southern Jalisco. Advance in Asian Social Science, 1(1), 18-19. 


\section{MInstitute Macrothink $_{\text {Intion }}$}

VNA. (2013). Hanoi ranks fifth among 10 attractive destinations in Asia. Retrieved from http://en.hanoi.vietnamplus.vn/;

http://en.hanoi.vietnamplus.vn/Home/Hanoi-ranks-fifth-among-10-attractive-destinations-inAsia/20139/2938.vnplus

VNAT. (2013). Hanoi ranks 5th in Asia's must-see sights. Retrieved from http://www.vietnamtourism.gov.vn/;

http://www.vietnamtourism.gov.vn/English/index.php/items/6285

VNAT. (2019a). Retrieved from http://vietnamtourism.gov.vn/english/; http://vietnamtourism.gov.vn/english/

VNAT. (2019b). Doanh nghiệp lũ hành quốc tế giai đoạn 2005-2018. Retrieved from http://vietnamtourism.gov.vn/; http://vietnamtourism.gov.vn/index.php/items/13466

WTTC. (2019). Vietnam 2019 annual research: Key Highlights. Retrieved from https://www.wttc.org/economic-impact/country-analysis/country-reports/

Zelenka, J., \& Pásková, M. (2012). The Explanatory Dictionary of Tourism. Praha: Linde Praha.

\section{Appendix A}

Descriptive Statistics and Reliability Analysis of the scale "The most important factor when travelling"

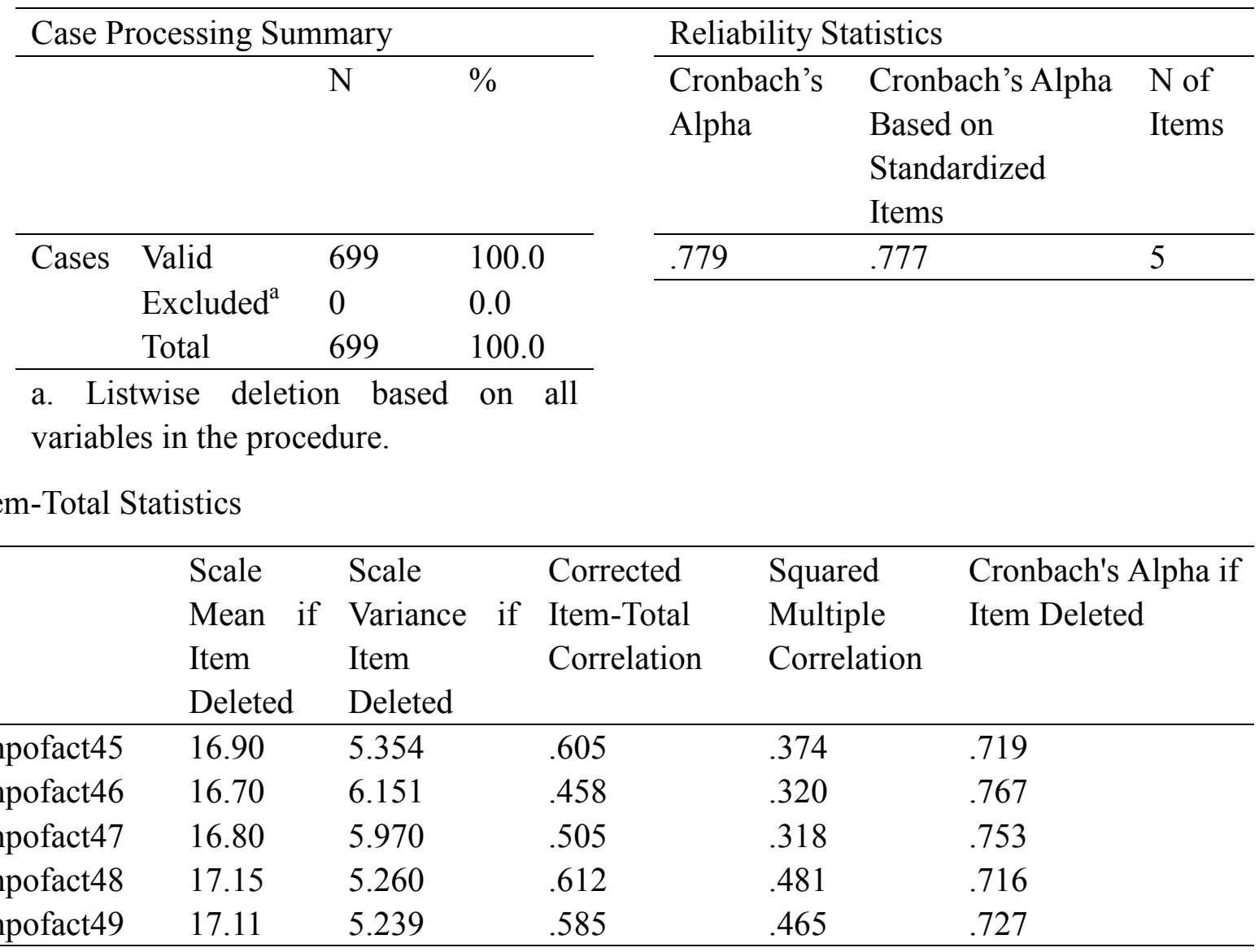


Impofact45

\begin{tabular}{llllll}
\hline & & Frequency & Percent & Valid Percent & Cumulative Percent \\
\hline Valid & Strongly disagree & 5 & .7 & .7 & .7 \\
& Disagree & 19 & 2.7 & 2.7 & 3.4 \\
& Neutral & 74 & 10.6 & 10.6 & 14.0 \\
Agree & 286 & 40.9 & 40.9 & 54.9 \\
Strongly agree & 315 & 45.1 & 45.1 & 100.0 \\
Total & 699 & 100.0 & 100.0 & \\
\hline
\end{tabular}

Impofact46

\begin{tabular}{llllll}
\hline & & Frequency & Percent & Valid Percent & Cumulative Percent \\
\hline Valid & Strongly disagree & 3 & .4 & .4 & .4 \\
& Disagree & 6 & .9 & .9 & 1.3 \\
Neutral & 55 & 7.9 & 7.9 & 9.2 \\
Agree & 237 & 33.9 & 33.9 & 43.1 \\
Strongly agree & 398 & 56.9 & 56.9 & 100.0 \\
Total & 699 & 100.0 & 100.0 & \\
\hline
\end{tabular}

Impofact 47

\begin{tabular}{llllll}
\hline & & Frequency & Percent & Valid Percent & Cumulative Percent \\
\hline Valid & Strongly disagree & 3 & .4 & .4 & .4 \\
& Disagree & 8 & 1.1 & 1.1 & 1.6 \\
Neutral & 60 & 8.6 & 8.6 & 10.2 \\
Agree & 286 & 40.9 & 40.9 & 51.1 \\
Strongly agree & 342 & 48.9 & 48.9 & 100.0 \\
Total & 699 & 100.0 & 100.0 & \\
\hline
\end{tabular}

Impofact 48

\begin{tabular}{llllll}
\hline & & Frequency & Percent & Valid Percent & Cumulative Percent \\
\hline Valid & Strongly disagree & 3 & .4 & .4 & .4 \\
& Disagree & 28 & 4.0 & 4.0 & 4.4 \\
Neutral & 133 & 19.0 & 19.0 & 23.5 \\
Agree & 325 & 46.5 & 46.5 & 70.0 \\
Strongly agree & 210 & 30.0 & 30.0 & 100.0 \\
Total & 699 & 100.0 & 100.0 & \\
\hline
\end{tabular}

Source: Data Analysis results. 


\section{Appendix B}

Quality evaluation statistic of Transportation

\begin{tabular}{|c|c|c|c|c|c|c|c|}
\hline \multicolumn{8}{|c|}{ Statistics } \\
\hline & & Tranf26 & Tranf27 & Tranf28 & Tranf29 & Tranf30 & Tranf31 \\
\hline \multirow{2}{*}{$\mathrm{N}$} & Valid & 697 & 699 & 698 & 699 & 699 & 699 \\
\hline & Missing & 3 & 1 & 2 & 1 & 1 & 1 \\
\hline \multicolumn{2}{|c|}{ Mean } & 3.9182 & 4.0343 & 4.0487 & 3.6452 & 3.4149 & 3.8069 \\
\hline \multicolumn{2}{|c|}{ Median } & 4.0000 & 4.0000 & 4.0000 & 4.0000 & 3.0000 & 4.0000 \\
\hline \multicolumn{2}{|c|}{ Std. Deviation } & .90998 & .88701 & .91563 & .97975 & 1.05690 & .86057 \\
\hline \multicolumn{2}{|c|}{ Minimum } & 1.00 & 1.00 & 1.00 & 1.00 & 1.00 & 1.00 \\
\hline \multicolumn{2}{|c|}{ Maximum } & 5.00 & 5.00 & 6.00 & 5.00 & 5.00 & 5.00 \\
\hline \multicolumn{2}{|c|}{ Sum } & 2731.00 & 2820.00 & 2826.00 & 2548.00 & 2387.00 & 2661.00 \\
\hline
\end{tabular}

Source: Data analysis results.

\section{Appendix C}

Quality evaluation statistic of Information and Promotion

\begin{tabular}{|c|c|c|c|c|c|c|}
\hline \multicolumn{7}{|c|}{ Statistics } \\
\hline & & Prom 32 & Prom33 & Prom34 & Prom35 & Prom 36 \\
\hline \multirow[t]{2}{*}{$\mathrm{N}$} & Valid & 699 & 699 & 699 & 699 & 699 \\
\hline & Missing & 1 & 1 & 1 & 1 & 1 \\
\hline \multicolumn{2}{|c|}{ Mean } & 3.6109 & 3.5122 & 3.8398 & 3.7268 & 3.6266 \\
\hline \multicolumn{2}{|c|}{ Median } & 4.0000 & 3.0000 & 4.0000 & 4.0000 & 4.0000 \\
\hline \multicolumn{2}{|c|}{ Std. Deviation } & .87480 & .85029 & .83619 & .83855 & .88892 \\
\hline \multicolumn{2}{|c|}{ Minimum } & 1.00 & 1.00 & 1.00 & 1.00 & 1.00 \\
\hline \multicolumn{2}{|c|}{ Maximum } & 5.00 & 5.00 & 5.00 & 5.00 & 5.00 \\
\hline \multicolumn{2}{|c|}{ Sum } & 2524.00 & 2455.00 & 2684.00 & 2605.00 & 2535.00 \\
\hline
\end{tabular}

Source: Data analysis results.

\section{Copyrights}

Copyright for this article is retained by the author(s), with first publication rights granted to the journal.

This is an open-access article distributed under the terms and conditions of the Creative Commons Attribution license (http://creativecommons.org/licenses/by/4.0/). 